\title{
A MODEL OF ORgANIZATIONAL CITIZENSHIP BEHAVIOR IMPROVEMENT BASED ON INSTRINSIC MOTIVATION AND ORgANIZATIONAL JUSTICE IN REgIONAL SECRETARIAT OF SEMARANg REgENCY
}

Ika Rusmawati ${ }^{1 *}$, Mutamimah $^{2 *}$

* Affiliation:

${ }^{1,2}$ Magister of

Management Program, Sultan Agung Islamic

University

\begin{abstract}
:
Good Organizational Citizenship Behavior (OCB) needs to be supported by a strong commitment from human resources since the stronger the employees' commitment, the higher the OCB will be. The improvemnet of Human Resource commitment needs to be supported by strong intrinsic motivation from human resources and organizational justice which is able to encourage human resources in improving organizational citizenship behavior (OCB). This study was conducted in Regional Secretariat of Semarang regency to 118 civil servants working there. Census was used as the sampling technique in this study in which every member of the population had the same opportunity to be taken as the research sample. Regressive analysis of path analysis model (path analysis) was used as the analysis technique. The research revealed that intrinsic motivation and organizational justice had a significant positive effect on organizational commitment and $\mathrm{OCB}$, while commitment had a significant positive effect on OCB.
\end{abstract}

Keywords : intrinsic motivation, organizational justice, commitment and OCB.

\section{INTRODUCTION}

The success in the management of governmental organization is strongly determined by the productivity of human resources. This is because human resources play a very important role in improving the performance of a governmental organization. Therefore it can be said that developmental activities cannot be separated from the improvement of human resources. Basically human beings do not only play a role as the development objects but they also play roles as thinkers, planners, and development executors.

Akanbi and Ajayi (2014) argue that performance also means a person's achievement in which both the quantity and the quality are appropriate to the given responsibility. The work of a person will 
give feedback to the person himself/herself. It makes him/her think that he/she will always be active in doing his/her work appropriately which is expected in resulting agood quality of work. Organizational Citizenship Behavior is a role of employees outside of their job descriptions that support the effectiveness of organizational activities (Shaiful and Ali, 2005). Satisfied employees are more likely to speak positively about the organization, help others, and make their work performance beyond the ordinary expectations. In addition, satisfied employees may be more obedient to the call of duty because they want to repeat their positive experiences. In fact, there is an evidence which show that satisfaction affects the Organizational Citizenship Behavior (OCB) through the perception of justice. The concept of organizational justice is shown by two perspectives: procedural justice that focuses on the attention of employees "how decisions are made" and distributive justice that refers to the perception of employees' justice towards the work of employees (Akhbari et al., 2013).

Chu and Shan (2007) state that individuals are interested in and comfortable to the organization due to the similarity of characteristics between the two. Chu and Shan, (2007) finds that the development of carrier and management will improve the motivation of customer's orientation behavior of the workers. Rizal et al. (2014) states that organizational justice is all incomes in the form of money, directly or indirectly received by employees as rewards or services provided to the institution. Akanbi and Ajayi (2014) express that motivation is a process that explains the intensity, direction and persistence of effort to achieve certain goal. Motivation is important because by having motivation every individual is expected to work hard and be enthusiastic in achieving high standard of OCB. Meanwhile, Matlhis and Jackson (2002) illustrate that motivation is an important factor influencing how and why people work in a certain organization. The compensation that is based on performance and employee skills seems to satisfy employees, so that employees are motivated to improve their performance and develop their skills.

OCB helps transform a formal organizational atmosphere into an atmosphere that is slightly relax and full of cooperation. It is expected that in such an atmosphere the tension among the employees can be reduced and the employees' productivity can be improved so that so that effectiveness will be achieved efficiently. The situation is also justified by Akhbari et al. (2013) which explains that OCB can facilitate the social life in an organization. OCB is explicitly described as something beneficial for employees in organizational life (Shaiful and Ali, 2015). Based on the description above, it is clear that a good OCB needs to be supported by strong commitment from human resources. The more committed the employees, the higher the OCB will be. The improvement of human resources commitment has to be supported by strong intrinsic motivation from human resources and organizational justice that are to encourage human resources in improving organizational citizenship behavior (OCB).

Based on the research gap between the study conducted by Ghanbari and Eskandari (2014) that reveals that intrinsic motivation will increase OCB and the study conducted by Santos (2015) that indicates that intrinsic motivation is not significant to OCB, then the conditions in the Regional Secretariat of Semarang, the problems of the research can be formulated. The problem in this research is the increase of employees' absence due to the low motivation. The increase of absence requires a high OCB so that the functional vacuum of an employee could 
be replaced by another employees. This condition causes the existence of intrinsic motivation effects on the OCB and this becomes the early indicator which causes the low level of OCB.

\section{LITERATURE REVIEW Intrinsic Motivation}

In management, intrinsic motivation is only directed to human resources in general and subordinates in particular. Intrinsic motivation also focuses on how to direct employees' power and potential to achieve the decided plan. The role of motivation in supporting the fulfillment of achievement needs is definitely important. In other words, motivation has a positive relationship to a better work performance and vice versa. Intrinsic motivation is a motivation that does not necessarily require the stimulation from the outside because it exists in the individual itself which in line with its' needs. Meanwhile extrinsic motivation exists because of the existence of stimulant form the outside, for example in educational field, a desire to learn something appears once a person realizes the benefit of it. Intrinsic motivation is stronger than extrinsic motivation. Therefore it is not surprising when human resources have high motivation, they will have high performance in work at the same time. Based on the explanation, a hypothesis can be formulated as follows:

\section{H1: If intrinsic motivation increases, affective commitment increases}

Akanbi and Ajayi (2014) explain that motivation is a process that explains the intensity, direction and persistence of effort to achieve certain goal. Meanwhile, Samsudin (2005) defines motivation as a process of influencing or encouraging externally to a person or a group of employees so that they want to do something that has been established. Motivation is important because by having motivation every individual is expected to work hard and be enthusiastic in achieving high standard of OCB. Akanbi and Ajayi (2014) show that intrinsic motivation has a positive effect on OCB.

\section{H2: If intrinsic motivation increases, $O C B$ increases}

\section{Justice Organizations}

Organizational justice in the Islamic view indicates that managers who have a high commitment to the Islamic organization justice will tend to have a moderate tendency toward individualism. Employees who are treated unfairly will try to take over the assets of the organization as ato balance the inequalities of the distribution of the resources they receive. Unfairness perceived by the employees will create the willingness to seek opportunities to improve their own welfare, even if they are unethical (Rokhman, 2015). Based on the description, a hypothesis can be formulated as follows:

\section{H3: When organizational justice increases, affective commitment increases.}

The implementation of an organizational rewarding system has an important impact on employees' attitudes and behavior (Chiu and Tsai, 2007). Organizational justice to employees motivates employees to work harder to improve the organizational performance overall.

Alkahtani (2015) states that whenever an organization has a system of reward and fairness, 
by giving bonuses related to performance, it can encourage an employee to perform civic behavior. Employees are motivated to focus on achieving the organization's goal of achieving profitability.

\section{Organizational Justice}

Khanifar et al. (2013) finds that organizational justice based on performance has a positive effect on organizational citizenship behavior. This research explains the characteristics and objectives of the organizational reward system that will have an impact on employees' civic behavior. One of them is performance-based justice. The work units or employees have targets that have been set out in the early period of assessment, and the results are reviewed formally in the mid-term and the end of periods, then evaluation is conducted and rewards are given for their performance in a fair manner. The formulation of hypothesis 4 is supported by previous research conducted by Alkahtani, Ali. (2015); Organs, (1993); and Khanifar et al. (2013). Based on the description, hypothesis 4 can be formulated as follows:

\section{H4: If organizational justice increases, $O C B$ increases.}

\section{Affective Commitment}

Affective commitment is based on behaviors which mainly come from the inadequacy of employees skills so that employees leave the organization that binds them. When commitment is exemplified as a function of trust to the organization and work experience, the character of the organization should be a factor affecting human resources' trust on the organization. Therefore, at the level of HR commitment; work characteristics should be the main factors affecting the satisfaction of wok and performance of human resources. Mohamed (2012) identifies that there is a significant positive relationship between sustainable commitment and Organizational Citizenship Behavior (OCB). Meyer et al. (1993) in Mohammed (2012), studied the relationship between Organizational Citizenship Behavior (OCB) and commitment including affective and normative commitment among employees. Based on the explanation, hypothesis 5 can be formulated as follows:

\section{H5: If affective commitment increases, $O C B$ increases.}

\section{Conceptual framework}

Based on the literature review, it can be explained that good OCB needs to be supported by a strong commitment of human resources. The stronger the employees' commitment, the higher OCB will be. The improvement of human resource commitment needs to be supported by strong intrinsic motivation from them and organizational justice that can encourage them to work better in order to improve OCB. 


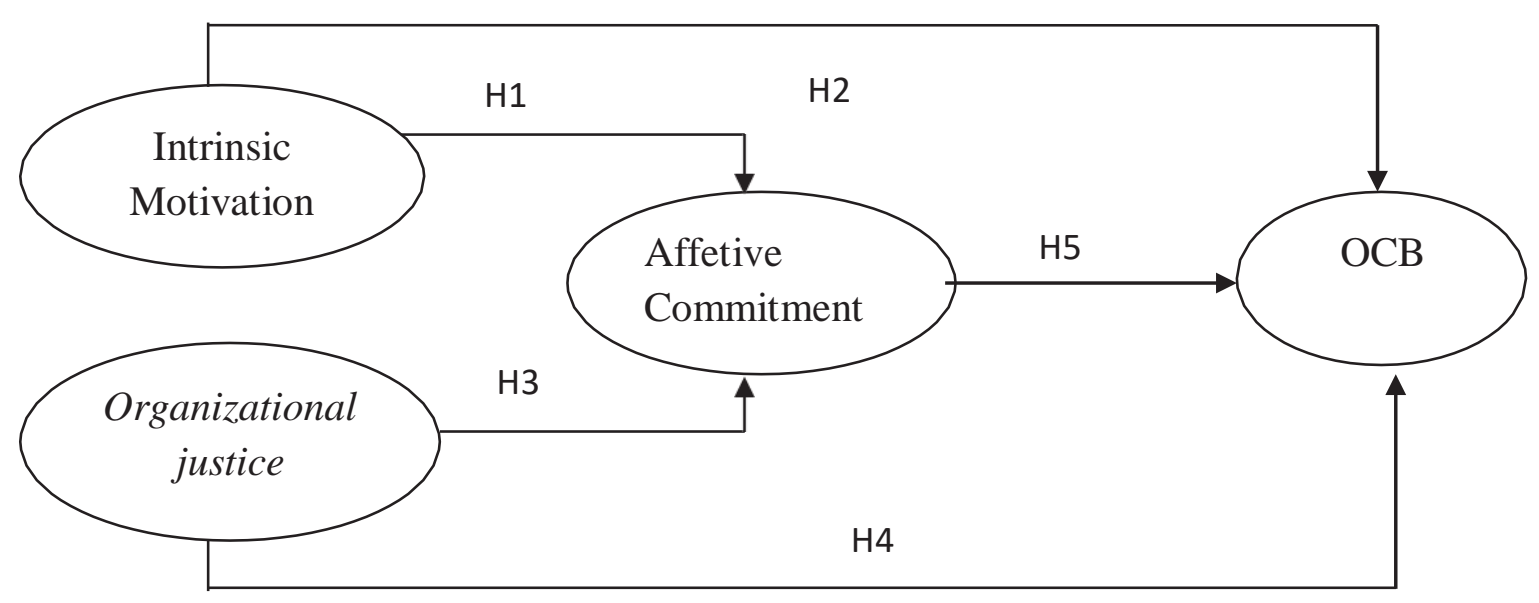

Figure 1. Conceptual Framework

\section{RESEARCH METHOD}

This study was conducted in Regional Secretary of Semarang regency to 118 civil servants working there. Census was used as the sampling technique in this study in which every member of the population had the same opportunity to be taken as the research sample. Regression analysis of path analysis model (path analysis) was used as the analysis technique.

\section{RESEARCH RESULTS AND DISCUSSION}

The regression equation for regression analysis results in the first model can be explained as follows:

\section{Affective Commitment $=0.249$ Instrinsic Motivation +0.857 Organizational Justice}

Based on the above equation, it can be explained that intrinsic motivation is able to increase affective commitment by 0.249 . The direction of positive regression coefficient shows the positive influence of intrinsic motivation to affective commitment. This indicates that employees who have strong intrinsic motivation have stronger affective commitments. Organizational justice is able to increase affective commitment by 0.857 . The direction of positive regression coefficient indicates the positive effect of organizational justice on affective commitment. This indicates that organizations with high organizational justice can increase employees' affective commitment.

The regression equation for regression analysis results in the second model can be explained as follows:

\section{OCB $=0.470$ Intrinsic Motivation +0.312 Organizational Justice +0.258 Affective Commitment}

Based on the above equation, it can be explained that intrinsic motivation is able to increase the OCB by 0,470 and the direction of positive regression coefficient shows the existence of positive effect of intrinsic motivation to OCB. This indicates that strongly selfmotivated employees are able to improve their OCB. Organizational justice is able to increase OCB by 0,312 and the direction of positive regression coefficient indicates the positive effect of organizational justice to OCB. This implies that organizations with high organizational justice 
can improve OCB. Affective commitment is able to increase OCB by 0,258 , the direction of positive regression coefficient indicates the positive effect of organizational justice on affective commitment. This result shows that organizations with high organizational justice can increase employees' affective commitment.

To test hypothesis by using t-test, regression analysis is required. The summary of data processing results using SPSS program for t-test is as follows:

Table 4. T-test

\begin{tabular}{llllcll}
\hline No & Dependent Variables & Independent Variables & $\mathbf{B}$ & $\mathbf{t}_{\text {statistic }}$ & Sign & Explanation \\
\hline 1 & Affective Commitment & Intrinsic Motivation & 0.249 & 2.014 & 0.045 & H1 Accepted** \\
\hline 2 & Affective Commitment & Organizational Justice & 0.857 & 11.257 & 0.000 & H2 Accepted** \\
\hline 3 & OCB & Intrinsic Motivation & 0.470 & 5.160 & 0.000 & H3 Accepted* \\
\hline 4 & OCB & Organizational Justice & 0.312 & 2.327 & 0.024 & H4 Accepted* \\
\hline 5 & OCB & Affective Commitment & 0.258 & 2.186 & 0.031 & H5 Accepted* \\
\hline
\end{tabular}

Source: Regression Output Result, 2017

From Table 4, multiple linear regression equation can be explained as the following.

\section{The Effect of Intrinsic Motivation (X1) on Affective Commitment (Y)}

Based on partial test, $\mathrm{X}_{1}$ (intrinsic motivation) variable has a regression coefficient of $0.249, \mathrm{t}_{\text {statistic }}$ score of 2.014 with significance of 0.045 . Because $t_{\text {statistic }}$ is higher than $\mathrm{t}_{\text {table }}\left(\mathrm{t}_{\text {statistic }}\right.$ $\left.2,014>\mathrm{t}_{\text {table }} 1,96\right)$, Ho is rejected and $\mathrm{Ha}$ is accepted. This shows that intrinsic motivation variable has a significant effect on affective commitment, then hypothesis 1 is acceptable. The direction of the positive regression coefficient indicates a positive effect of intrinsic motivation on affective commitment. This indicates that employees who have strong intrinsic motivation have stronger affective commitments.

\section{The Effect of Organizational Justice (X2) on Affective Commitment (Y)}

Based on partial test, $\mathrm{X}_{2}$ (organizational justice) variable has a regression coefficient of $0.857, \mathrm{t}_{\text {statistic }}$ of 11.257 with a significance of 0.000 . Because $t_{\text {statistic }}(11.257)$ is higher than $t_{\text {table }}$ (1.96) $\left(\mathrm{t}_{\text {statistic }}>\mathrm{t}_{\text {table }}\right)$, Ho is rejected and $\mathrm{Ha}$ is accepted. This describes that organizational justice variable has a significant effect on affective commitment, then hypothesis 3 is acceptable. The direction of the positive regression coefficient shows the positive effect of organizational justice on affective commitment. This implies that organizations with high organizational justice can increase employees' affective commitment.

\section{The Effect of Instrinsic Motivation (X1) to OCB (Y)}

Based on partial test, XI (intrinsic motivation) variable has a regression coefficient of 0.470 , tstatistic of 5.160 with significance of 0.000 . Because $t_{\text {statistic }}(5.160)$ is higher than $\mathrm{t}_{\text {table }}(1.96)\left(\mathrm{t}_{\text {statistic }}>\mathrm{t}_{\text {table }}\right)$, Ho is rejected and Ha is accepted. This result indicates that intrinsic motivation variable has significant effect on OCB, then hypothesis 2 is accepted. The direction of positive regression coefficient implies a positive influence of intrinsic motivation on OCB. 
This indicates that strongly self-motivated employees are able to improve OCB. 


\section{Effect of Organizational Justice (X2) on OCB (Y)}

Based on the partial test, X2 (organizational justice) variable has a regression coefficient of 0.312 , tstatistic of 2.327 with a significance of 0.024 . $\mathrm{T}_{\text {statistic }}(2.327)$ is higher than $\mathrm{t}_{\text {table }}(1.96)$ $\left(\mathrm{t}_{\text {statistic }}>\mathrm{t}_{\text {table }}\right)$, so that Ho is rejected and Ha is accepted. This shows that organizational justice variable has a significant effect on OCB, then hypothesis 4 is accepted. The direction of the positive regression coefficient indicates the positive effect of organizational justice on OCB. This result indicates that organizations with high organizational justice can improve OCB.

\section{Effect of Affective Commitment (X2) on OCB (Y)}

Based on the partial test, X2 (affective commitment) variable has a regression coefficient of 0.258 , tstatistic of 2.186 with a significance of $0.031 . \mathrm{T}_{\text {statistic }}(2.186)$ is higher than $t_{\text {table }}(1.96)\left(t_{\text {statistic }}>t_{\text {table }}\right)$, so that Ho is rejected and Ha is accepted. This result suggests that the affective commitment variable has a significant effect on OCB, then hypothesis 5 is accepted. The direction of positive regression coefficient indicates a positive influence of affective commitment to OCB. This indicates that employees with high affective commitment are able to improve OCB.

The overall regression test was done by using $\mathrm{F}$ test. This test was conducted using 5\% significance level.

Table 5. F-Test Equations 1

\begin{tabular}{lllllll}
\hline Model & & Sum of & & Mean \\
Squares & df & Square & F & Sig. \\
\hline 1 & Regression & 61.467 & 3 & 20.489 & 40.953 & 0.000 \\
& Residual & 50.531 & 101 & 500 & & \\
& Total & 111.998 & 104 & & & \\
\hline
\end{tabular}

The result of the f-test shows that the feasibility of the model has an estimated $\mathrm{F}$ of 40.953 with a significance of 0,000 . It means that if $F$ statistic (40.953) is higher than $\mathrm{F}$ table (1.96) and the significance value (0.000) is lower than 0.05 , it is indicated indicated that the model is appropriate to be examined.

Table 6. F-Test Equation 2

\begin{tabular}{ccccccc}
\hline & & Sum of & \multicolumn{3}{c}{ Mean } \\
\multicolumn{1}{c}{1} & Model & Squares & df & Square & F & Sig. \\
\hline & Regression & 64.925 & 2 & 32.463 & 108.448 & 0.000 \\
& Residual & 30.532 & 102 & 0.299 & & \\
& Total & 95.457 & 104 & & & \\
\hline
\end{tabular}

The result of the f-test shows that the feasibility of the model has an estimated $\mathrm{F}$ of 108,448 with a significance of 0,000 , meaning that if $F$ statistic (108.448) is 108.448 higher than F table (1.96) and the significance value (0.000) is lower than 0.05, it indicates that the model is suitable to be examined. 
Coefficient of determination is an indicator of the effect of independent variables on the dependent variable. The coefficient of determination is shown by value of adjusted R2.

Table 7. Measurement Model

\begin{tabular}{llll}
\hline No & Dependent Variable & Independent Variable & $\mathbf{R}^{\mathbf{2}}$ \\
\hline 1 & Affective Commitment & Intrinsic Motivation and Organizational Justice & 0,674 \\
& OCB & Intrinsic Motivation, Organizational Justice and Affective & 0,535 \\
& & Commitment & \\
\hline
\end{tabular}

Source: Multiple Regression Analysis Results Output

(2017)

Coefficient of determination is an indicator of the effect of independent variables on the dependent variable. The coefficient of determination is shown by adjusted $\mathrm{R} 2$ value. The result of adjusted $\mathrm{R} 2$ value is 0,674 . This implies that $67.4 \%$ of affective commitment can be explained by intrinsic motivation and organizational justice, while the remaining $32.6 \%$ affective commitment is influenced by other variables which are not included in this model. This result implies that affective commitment is not only influenced by intrinsic motivation and organizational justice, but there are other variables that affect affective commitment.

The result of adjusted R2 value is 0,674 . This indicates that $53.5 \%$ of OCB can be explained by intrinsic motivation, organizational justice, and affective commitment while the remaining $46.5 \%$ OCB is influenced by other variables which not included in this model. This result describes that $\mathrm{OCB}$ is not only influenced by intrinsic motivation, organizational justice, and affective commitment but there are other variables that influence OCB.

\section{DISCUSSIONS}

Based on the result of the test, hypothesis 1 is accepted, in which the direction of positive regression coefficient shows the positive influence of intrinsic motivation on affective commitment. This result shows that employees who have strong intrinsic motivation have stronger affective commitment. Employees who have intrinsic motivation want to be given a challenge to achieve certain goals, an opportunity to contribute to their work company, and an opportunity to reach all of their potential in the workplace.

Employees having motivation to achieve success in the implementation of their duties will be increasingly encouraged to have a sense of belonging to the organization or a willingness to be part of the organization. Similarly, employees having a strong sense of responsibility for their work will further improve their performance and their sense of belonging. Employees who have a strong desire to develop their competencies and skills within the organization will improve their performance and feel happiness of being a part the organization for they feel that they are able to develop their competencies and skill within the organization. The results of this study support a research conducted by Kreitner and Kinicki (2012).

Based on the result of the test, hypothesis 2 is accepted in which the direction of positive regression coefficient shows a positive effect of intrinsic motivation on OCB. This indicates that employees who have strong intrinsic motivation are able to improve OCB. Motivation is important because by having motivation every individual is expected to work hard and be 
enthusiastic in achieving high standard of OCB. Employees having a strong desire to achieve success in the implementation of their duties will further improve their performance and they will even be willing to complete other work that is not their main duty in order to achieve the organizational success. Employees having great responsibility for tasks and works assigned to them will further enhance their performance to achieve the organizational goals. In the same way, employees with a strong desire to develop their comptencies and skills will be increasingly encouraged to improve their performance. Then, they will try to obey all of the regulations and procedures applied in the organization for the sake of the improvement of the organization which will also facilitate the development of their competencies and skills. This is a phenomenon in the Regional Secretariat of Semarang Regency where the employees feel that their strong motivation to achieve successes, responsibility, and development of competence are able to enhance their performance to help colleagues' work such as submitting reports and obeying the rules and procedures applied in the organization in order to achieve the improvement of the organization. These findings support Rokhman's research, (2015).

Based on the result of the test, hypothesis 3 is accepted in which the direction of positive regression coefficient shows the positive effect of organizational justice on affective commitment. This denotes that organizations with high organizational justice can increase employees' affective commitment. Organizational justice in the Islamic view indicates that managers who have a high commitment to the Islamic organization justice will tend to have a moderate tendency toward individualism. Employees who are treated unfairly will try to take over the assets of the organization as ato balance the inequalities of the distribution of the resources they receive. Unfairness perceived by the employees will create the willingness to seek opportunities to improve their own welfare, even if they are unethical. Employees who feel that they are treated fairly by given opportunities to develop their career, to express their opinions both in the form of suggestions and inputs which support the success of the organization, to have a good relationship with employers, and to get facilities supporting the implementation of their work, will feel happiness of being a part of the organization, feel a sense of belonging and try to increase their performance for the improvement of the organization. Similarly, this condition happens in the Regional Secretariat of Semarang regency where employees feel that they are treated fairly in the organization. As a result they will increase their affective commitment within the organization. The results of this study support a study conducted by Akanbi and Ajayi (2014).

Based on the result of the test, hypothesis 4 is accepted in which the direction of positive regression coefficient describes the positive effect of organizational justice on OCB. This condition indicates that organizations with high organizational justice can improve OCB. Performance-based organizational justice has a positive effect on organizational citizenship behavior. This study describes the characteristics and objectives of the organizational reward system that will have an impact on employees' civic behavior. One of them is performancebased justice. The work units or employees have targets that have been set out in the early period of assessment, and the results are reviewed formally in the mid-term and the end of periods, then evaluation is conducted and rewards are given for their performance in a fair manner. By having this system, employees will be encouraged to try to increase their extra 
performance in order to support the improvement of the organization. The results of this study support the study done by Alkahtani, Ali. (2015); Organs, (1993); and Khanifar et al. (2013).

The result of hypothesis testing shows that hypothesis 5 is accepted. The direction of positive regression coefficient indicates a positive effect of affective commitment on OCB. This result is able to explain that employees having high affective commitment are able to improve $\mathrm{OCB}$. Affective commitment is based on behaviors which mainly come from the inadequacy of employees skills so that employees leave the organization that binds them. When commitment is exemplified as a function of trust to the organization and work experience, the character of the organization should be a factor affecting human resources' trust on the organization. Therefore, at the level of HR commitment; work characteristics should be the main factors affecting the satisfaction of work and performance of human resources. The results of this study support the previous research conducted by Mohammed, (2012).

The result of calculation of direct effect, indirect effect and total effect in this research can be explained as follows:

Table 7. Direct, Indirect and Total Effects

\begin{tabular}{lllll}
\hline Variable & Effect & $\begin{array}{l}\text { Intrinsic } \\
\text { Motivation }\end{array}$ & $\begin{array}{l}\text { Organizational } \\
\text { Justice }\end{array}$ & $\begin{array}{l}\text { Affective } \\
\text { Commitment }\end{array}$ \\
\hline \multirow{2}{*}{$\begin{array}{llll}\text { Affective } \\
\text { Commitment }\end{array}$} & Direct & 0,249 & 0,857 & $\cdot$ \\
& Indirect & $\cdot$ & $\cdot$ & $\cdot$ \\
& Total & 0,249 & 0,857 & $\cdot$ \\
OCB & Direct & 0,470 & 0,312 & 0,258 \\
& Indirect & 0,064 & 0,221 & $\cdot$ \\
& Total & 0,534 & 0,533 & 0,258 \\
\hline
\end{tabular}

Based on Table 4.5 above it can be explained that the direct effect of intrinsic motivation to OCB is higher than the indirect effect to OCB in which direct effect is 0.470 and the indirect effect is 0.064 . This indicates that employees having high intrinsic motivation will work better and have a high commitment to improve OCB.

The direct effect of organizational justice to OCB is higher than the indirect effect to OCB, in which the direct effect is 0.312 and the indirect effect is 0.221 . This suggests that employees who are treated fairly with organizational justice will work better and have higher commitment to improve OCB.

\section{CLOSINg}

This part describes the conclusions of the research findings, managerial implications, research limitations, and future research agenda.

\section{HYPOTHESIS CONCLUSIONS}

Based on the calculation of multiple regression with SPSS program version 22.0, the hypothesis conclusions can be drawn as follows: 
1. Affective commitment is built by indicators of intrinsic motivation that include achievement, recognition, work it self, responsibility and advancement.

2. Affective commitment is built by organizational justice indicators that include incentive increments, career opportunities, opportunities to express opinions, relationship between superiors and subordinates, and facilities provided.

3. Organizational behavior is built by indicators of intrinsic motivation including achievement, recognition, work it self, responsibility and advancement.

4. Organizational behavior is built on organizational justice indicators that cover incentive increments, career opportunities, opportunities for voicing opinions, the relationship between superiors and subordinates, and the facilities provided.

5. Organizational citizen behavior is built by indicators of affective commitment including strong sense of belonging with the organization, sense of being proud of giving information about the organization to others, and sense of happiness to work in the organization until the retirement period.

\section{PROBLEM FORMULATION CONCLUSIONS}

Based on the significant support of hypothesis testing, the research problems have been addressed, which resulted in 2 development of the improvement behavior of organizational members as the following:

- First, steps to improve the organizational citizenship behavior which are reinforced by intrinsic motivation thriugh the mediation of affective commitment

- Second, steps to increase the organizational citizenship behavior which are reinforced by organizational justice through the mediation of affective commitment

\section{MANAgERIAL IMPLICATIONS}

The managerial implications in this study can be explained through the following points:

The Regional Secretariat of Semarang regency needs to increase the intrinsic motivation of the employees through trainings, rotations and rewards. This organization needs to provide periodical training to the employees to increase their motivation. The organization also needs to do rotation to povide refreshment to the employees so that they will not get saturated with their work.

Regional Secretariat in Semarang regency needs to increase affective commitment through education and training that make the employees able to master their work. Assigning tasks sistematically is able to provide good OCB. This government organization needs to provide wide opportunity for employees to develop their ability and knowledge by giving such opportunities as joining trainings regularly, continuing study either through scholarship given by the organization or through the employees' own budget, and giving promotion for those who are potential.

Regional Secretariat of Semarang needs to increase organizational justice through increasing the employees' competencies and skills to be more innovative in performing their work. Employees who are able to improve their competencies and skills, their welfare will be increased as well. This organization also needs to provide equal rewards for employees by 
providing salary and allowances according to the achievement of the work. Take for example, giving $T H R$, providing leave allowance, and arranging family gathering once a year for improving the relationship among employees' family.

\section{LIMITATIONS OF RESEARCH}

Some of the limitations of the research that can be drawn from this research are as follows. Variables that explain the organizational citizenship behavior in Regional Secretariat of Semarang regency are still low. This is indicated by coefficient determination value which is low. The results of this study and the limitations found in the research can be a source of ideas for the development of this research in the future. Thus the researcher suggests to add independent variables that affect the organizational citizenship behavior. The recommended variables are: task variation, work experience, control and so forth.

\section{REFERENCE}

Akanbi, Paul Ayobami; and Ajayi Crowther, 2014, "Influence of Intrinsic and Extrinsic Motivation on Employees Performance",Working Paper Servicess in Business Administration

Akhbari, Maryam; Negar Tabesh; and Vahid Ghasemi, 2013, "Perceived Organizational Justice, Job Satisfaction, and OCB: How Do They Relate To Each Other",Journal of Basic and Applied Scientific Research

Alamzeb Aamir; Khawaja Jehanzeb; Anwar Rasheed; Omair Mujahid Malik, 2012, "Compensation Methods and Employees Motivation",International Journal of Human Resources Studies

Asim, Masood, 2013, "Impact of Motivation on Employee Performance WithEffect of Training",International Journal of Scientific and Research Publication

Chu, Hui Chin and Shan Chih Chang, 2007, “A Study of Career Development, Learning Motivation, Learning Satisfaction ofAdult Learners",Working Paper Servicess in Business Administration

Chiu, Li Yueh and Tsai Ping Ping, 2007,"Examining the Effect of Organization Cyulture and Leadership Behaviors on Organizational Commitment, Job Satisfaction, and Job Performance at Small and Middle-sized Firms of Taiwan”, The Journal of American Academy of Business.

Dana, Mubasyir Hasanbasri, 2007, "Hubungan Kepuasan Kerja dan Komitmen afektif Dengan OCB di Politeknik Kesehatan Banjarmasin”, Working Paper Serries

Fuad Mas'ud, 2004, Survai Diagnosis Organisasional (Konsep dan Aplikasi), Badan Penerbit Universitas Diponegoro.

Ghanbari, Siroos and Asghar Eskandari, 2014, "Organizational Climate, Job Motivation and OCB”,International Journal of Management Perspective 
Ghozali, 2011, Aplikasi analisis Multivariate dengan Program SPSS, Badan Penerbit

UNDIP , Semarang.

Hair, J.F.,Jr.,R.E. Anderson, R.L., Tatham \& W.C. Black, 1995, Multivariate Data Analysis With Readings, Englewood Cliffs, NJ: Prentice Hall.

Hafiza, Nadia Sajad; Syed Sohaib Syah; Humeera Jamsheed; and Khalid Zaman, 2011, "Relation BetweenRewards and Employee Motivation”, Bussiness Inteligence Journal.

Hameed, Abdul; Muhammad Ramzan; Hafiz M Kashif Zubair; Ghazanfal Ali, and Muhammad Arslan, 2014, "Impact of Compensation on Employee Performance", International Journal of Bussiness and Social Science

Huei, Tan Yew; Nur Naha Abdul Mansor; and Huam Hon Tat, 2014, "Role of OCB and Demographic Factors in The Relationship of Motivation and Employee Performance", Omnia Science

Khanifar, Hossein; Seyed Reza Razavi Saeedi; and Samereh Shojaee, 2013, "Managements Citizenship Behavior: Definitions, Formations and The Consequences in Organization",International Journal of Bussiness and Social Science

Lawrence, Janet; Molly Ott; and Alli Bell, 2011, "Faculty Organizational Commitment and Citizenship",Working Papper Servicess in Business Administration

Mwanje, Sarah MKN, 2004, "Career Development and Staff motivation in The Banking Industry", Journal of Management

Organ, Dennis W, and Robert H. Moorman, 1993, "Fairness and Organizational Citizenship Behavior : What Are The Connections?", Social Justice Research, Vol 6, No 1

Patrick, Andrew Harold, and Amit Kumar, 2011, "Career Management, Employee Development and Performance in Indian Information Technology Organizations", Journal of Management

Perkins, Stephen J, 2014, "Fostering Organizational Citizenship Behavior in UK Banks", Journal of Management

Rifai, Harif Amali, 2005, “A Test of the Relationships Among Perceptions of Justice, Job Satisfaction, Affective Commitment and OCB”, Gadjah Mada International Journal of Bussiness, May-August. Vol. 7. No. 2 p. 131-154

Rizal, Muhammad;M Syafii Idrus; Djumahir danRahayu Mintarti, 2014,"Effect ofCompensation on Motivation, Organizational Commitment on Employee Performance",International Journal of Business and Management Invention

Robbins, Stephen, 2007, Perilaku Organisasi. Prentice Hall, PT Indeks Kelompok Gramedia, Edisi Bahasa Indonesia, Edisi Kesepuluh

Rokhman, Wakhibur, (2015), “Etika kerja Islam dan keadilan organisasi,” Jurnal Penelitian Santos, Lanie M, (2015), "Leader member exchange and OCB at de la sale lipa," Journal of Management 
Schroeder, Tiffany, 2014, "Explaining OCB: A Critical Review of TheSocial Exchange Perspective", Journal of Management

Shaiful Annuar Khalid and Hasan Ali, 2005," Self and Superior ratings of organizational citizenship behaviour: Are there differences in the sources ratings," The International Journal of Educational Management

Singh, Akhilendra K; and AP Singh, 2010, "Career Stage and OCB Among Indian Managers ', Journal of The Indian Academy of Applied Psychology

Ueda, Yutaka, 2012, "OCB in Japanesse Organization: The Effect Job Involvement, Organizational Commitment, and Collectivism",Journal of Behavioral Studies in Bussiness

Ueda, Yutaka, 2013, "Effects of Workers Careers and Family Situations on OCB-Related Work Values", International Journal of Business and Management, Vol 8, No. 10

Zhang Ying Ying, 2004, "The Impact of Performance Management System on Employee Performance", Journal of Management 